\title{
associação COMERCIAL de São paULO INSTITUTO JURÍDICO
}

\author{
I - INOVAÇÕES QUE PODERIAM SER INTRODUZIDAS PARA: \\ a) PARTICULARMENTE MELHORAR O DECRETO-LEI 1075, \\ DE 22 DE JANEIRO DE 1970; \\ b) DE UM MODO GERAL, A PRÓPRIA LEI \\ DE DESAPROPRIAÇÕES *
}

ARRUDA ALVIM

Consultor Jurídico da Associlação Comercilal de São Paulo e Professor livre-docente da Faculdade Paulista de Direito, da Universidade de Católica de São Paulo

\section{INTRODUÇÃO: DESAPROPRIAÇÃO E OS SEUS MAIS GRAVES PROBLEMAS}

Deve-se ter presente que o problema mais importante na desapropriação, principalmente do ponto de vista prático, é o relacionado com a fixação do que seja justo valor, ( $V$. sôbre êste ponto a monografia de José Canasi, El Justiprecio en la expropriación pública, 1952, Buenos Aires, Roque Depalma editor, cap. I, n. 1, pág. 3).

Principalmente, depois da primeira guerra mundial, com as distorções constatadas nos sistemas econômicos, ou se se quiser, com o agravamento de tais anomalias, o problema da flutuação do valor do dinheiro assumiu proporções muito sérias. Na realidade, o problema da inflação, pode ser considerado o eixo, de onde irradiam inúmeros outros problemas. Segundo muitos, entreianto, a variação do poder aquisitivo do dinheiro é reflexo das arritmias que perturbam a vida econômica e não o eixo dessas arritmias. Autores entendem, que a variação do poder aquisitivo do dinheiro coloca-se, quer

* Trabalho apresentado ao Instituto Jurídico da Ássociação Comercial de São Paulo, a pedido do seu Superintendente, dr. Carlos Casimiro Costa, aí relatado e discutido, com suas conclusões aprovadas. 
como efeito, quer como causa, num autêntico círculo vicioso dos fenômenos inflacionários, donde, então, a necessidade de solução draconiana, em maior ou menor escala, proporcionada pelas técnicas econômicas, destinadas a superar ou a minorar o fenômeno da inflação. (V. sôbre o assunto na obra intitulada "INFLAÇÃO", de 1965, Rio de Janeiro, publicação da Usaide, pág. 3 e seguintes e 66 e seguintes, respectivamente, os trabalhos de Émile James "Um Estudo Geral da Inflação de Após-Guerra" e de Howard S. Ellis, "Os efeitos da Inflação do Após-Guerra sôbre os Ciclos e Crescimento Econômico").

Se a economia se ressente de tal fenômeno indesejável, certamente o direito é a êle sensível. $O$ dinheiro é o padrão através de cuja medida se constituem pràticamente e se solvem grande parte das obrigações, variando tal padrão, consideràvelmente, a pessoa que deverá recebê-lo, em contra-prestação de entrega da coisa, por exemplo, possivelmenie ficará prejudicada. E tanto mais prejudicada ficará, na razão direta em que não tiver tido a possibilidade de prever - percentual da inflação, quando se constituíra a obrigação.

Localizando o assunto, especificamente, no campo da expropriação, há que se dizer que, por diversas razões, a problemática do valor da indenização é afetada. E sendo atingida, deverá ser defendida, quer legalmente, quer jurisprudencialmente. Lei e Tribunais devem irmanar-se na defesa do expropriado, eis que a Constituição Ihe garante indenização, justa e prévia.

As desvantagens para o expropriado, no que tange ao assunto do preço, em nosso sentir, sobrepujam aquelas existentes para todos os que negociam normalmente, nas épocas de inflação. $E$ isto, pelas duas fundamentais seguintes razões: $1^{\circ} .^{\circ}$ ○ expropriado não pode prever e, nem evitar, o momento da expropriação, ficando, assim, submetido inexoràvelmente à vontade do Poder Público que, em têrmos práticos, é o juiz da conveniência ou não de desapropriar; $\left.2 .^{\circ}\right)$ de outra parte, mesmo obtendo indenização, a demora do pagamento vai contra o expropriado, porquanto não tem êle meios autênticamente e eficientes para obter, desde logo, o pagamento.

Quanto ao primeiro inconveniente, de ficar o expropriado submetido à desapropriação ou não, é êle inevitável. Justifica-se, jurìdicamente a permanência do direito de expropriar, pela circunstância, hodiernamente axiomática, em Direito, de que o interêsse público supera o do particular.

Quanto, porém, às consequências oriundas da execução prática 
da expropriação, particularmente tendo em vista o problema da atribuição de valor e seu pagamento em dinheiro, os sistemas variam. Parece que os danos da demora no pagamento, podem ser minorados, se se atender para dois aspectos, aos quais o legislador ordinário tem de dar solução terapêutica, e que são os seguintes: $1^{\circ} .^{\circ}$ fazer com que o expropriado, já na imissão liminar, em favor do Poder Público, receba o maior quantum possível, de molde a que, o crédito eventualmente verificado a seu favor, durante o processo, seja o menor possível, com o que, mesmo havendo demora, será ela menos danosa; $\mathbf{2}^{\circ}$ ) de qualquer forma, porém, para a hipótese da demora, deverá haver correção monetária integral, ou seja, que cubra tôda a demora, e não condicionada como acontece atualmente a ter-se passado um determinado prazo, sob pena de, mesmo havendo inflação, se o prazo for pequeno, inocorrer a possibilidade de aplicação da correção monetária.

De outra parte, consideraremos, ainda o problema de dever (ou de poder, mesmo) o legislador ordinário, discriminar quem receba liminarmente mais, dando, desta forma, previlégio a algumas classes e a outras não, como se verifica com o vigente Decreto-lei 1.075, criticando conseqüentemente a solução aí eleita.

Anies, porém, passemos, ràpidamente, a fixar as linhas mestras do instituto da expropriação.

\section{1 - Conceito de desapropriação e seu regime jurídico constitucional}

Interessa-nos considerar, nesta primeira parte do trabalho, especialmente o problema relativo à desapropriação de imóveis exclusive - problema da desapropriação da propriedade territorial rural, cuja forma de indenização - conquanto também deva ser justa e prévia, pode ser feita em títulos especiais da dívida pública.

Principalmente, ainda, trataremos do problema com nossa atenção centrada na imissão de posse, tendo em vista a situação dela derivante face à disciplina jurídica ordinária existente e particularmente estudada à luz dos dispositivos de nível constitucional, relativos ao problema.

Há que se estudar o assunto, procurando o mais rigoroso ajustamento da legislação ordinária à constitucional, a saber: $\left.11^{\circ}\right)$ quer criticando o sistema existente; $2 .^{\circ}$ ) quer, consequentemente, oferecendo as soluções energidas das críticas. 
O instituto da desapropriação assenta-se em diversos setores do nosso ordenamento jurídico, privado a saber: a) - no direito administrativo, porquanto o decreto espropriatório é ato administrativo; b) - no direito processual civil, pela circunstância de a expropriação, geralmente, ser realizada em processo judicial através da intervenção do Poder Judiciário; c) - no direito civil, pela seguinte principal circunstância: A - a desapropriação, encarada do ponto de vista do direito civil, guarda longínqua similitude com a figura da alienação, mais parecendo com uma alienação compulsória, pois verifica-se entrega da coisa, de um lado, e de outro, pagamento do preço; diferencia-se, todavia, da alienação pròpriamente dita, onde é essencial a vontade do alienante, a qual assume formas concretas na entrega da coisa, bem como a fixação do preço; $B-$ e, como resultante da alienação, ocorre que a coisa passa do domínio privado, para o domínio público, ficando então a pertencer ao desapropriante.

A desapropriação pode-se definir "como o procedimento através do qual o Poder Público, compulsòriamente, por ato unilateral, despoja uma pessoa de um bem certo, fundado em necessidade pública ou inierêsse social, mediante indenização, prévia e justa, pagável em dinheiro" (Prof. Celso Antonio Bandeira de Mello, preleções do Curso de Direito Administrativo, ministradas na Pontifícia Universidade Católica de São Paulo). O clássico Santi Romano bem fixou um aspecto capital da expropriação, que consiste em que, por seu intermédio se opera, verdadeiramente, substituição de proprietário e de propriedade. O Poder Público passa a ser proprietário do bem, sendo que o bem expropriado é substituído pelo seu valor econômico equivalente. Disse o seguinte que, na realidade se dá a "conversione forzata di un diritto individuale in un altro diritto che ne rappresenti il valore economico" (Cf. Santi Romanó, Corso di diritto amministrativo, 1932, 2. ${ }^{a}$ ed., Pádua, pág. 307; v. ainda fixando a mesma idéia, v. Liñares Quinta, Tratado de la Ciencia del Derecho Constitucional, argentino y comparado, - 1956, Buenos Aires, ed. Alfa, tomo IV, n. 2.550, pág. 124).

É tão marcante a nota da coercibilidade na expropriação, oriunda do Poder Estatal, que Liñares Quintana (op. cit. tomo IV, n. ${ }^{\circ} 2.501$, pág. 125), entende mesmo, à falta de norma autorizando expropriar, poderá fazê-lo o Poder Público, eis que tal direito é diretamente radicado na própria soberania; quem é soberano, pode expropriar. A idéia é interessante, porém, algo discutível, num contexto de Estado-de-Direito. Serve, porém, para dar a idéia de que sendo inevitável a expropriação, deverá também o legislador constitucional e, assim 
o ordinário, munir os cidadãos de tais garantias, que o amparem, na defesa de suas propriedades.

Tôda a disciplina jurídica ordinária (do direito administrativo, processual e civil), tem que guardar contudo a mais rigorosa observância do preceito constitucional regente do tema, que dispõe: "É garantido o direito de propriedade, salvo o caso de desapropriação por necessidade ou utilidade públicas ou por interêsse social, mediante prévia e justa remuneração em dinheiro,... (Emenda Constitucional n. ${ }^{\circ} 1$, artigo 153, § 22)".

Assim, não é possível desconhecerem-se os requisitos constitucionais, que informam o direito positivo ordinário. Êste tem de se amoldar àquele, realizando-o pràticamente. Desta forma, a desapropriação no direito positivo brasileiro, consiste numa forma de retirada de um bem do particular, passando do domínio dêste para o domínio do ente público, que o venha a desapropriar, mediante processo judicial ou não, com base nos motivos que permitem a desapropriação, e pagando-se ao particular, em dinheiro, prévia e justa indenização. Exclue-se, dêste conceito, a desapropriação cujo pagamento não seja feito em dinheiro. (artigo 161, Emenda Constitucional n. ${ }^{\circ} 1$; deixa-se de discutir, também, a possibilidade de o particular, mesmo em desapropriação que não seja rural aceitar outras formas de pagamento - Artigo 153, § 22, Emenda Constitucional n. ${ }^{\circ}$ 1).

\section{2 - A realidade prática como subsídio fundamental na apreciação crítica de um diploma legal.}

Na crítica de uma lei, com vistas à respectiva reformulação, é menos importante considerarem-se os aspectos estritamente jurídicos da mesma, mas sim encarar-se a realidade social sôbre a qual ela incide, e verificar se as soluções por ela permitidas atingem os fins a que a lei se desî́ina. Mas, ainda, no caso, há que se ver se a lei ordinária permite a plena realização dos fins propostos pelo legislador constitucional. Certamente, pois, também, nesta perspectiva, é indispensável ter-se presente a disciplina constitucional. Consideraremos a realidade social, partindo da mesma para procurar formular algumas soluções destinadas a tentar melhorar a disciplina das desapropriações, sempre à luz e indo ao encontro do direito constitucional positivo. De outra parte, o preceito constitucional, determinando - pagamento justo e prévio, e em dinheiro, para que sejam possíveis as desapropriações, quer por necessidade, quer por utilidade públicas, quer ainda, por interêsse social, não é, em si considerados, merecedor de crítica alguma. 
Na verdade, a ação expropriatória é, na quase totalidade das vêzes, uma ação executiva. E isto pela circunstância de que, liminarmente, o poder expropriante é imitido na posse dos bens. A Lei das Desapropriações, lei básica, baixada como o decreto-lei 3.365, de 21 de junho de 1941, disciplina no seu artigo 15, a possibilidade de, alegada urgência, e mediante certo depósito em dinheiro, seja o expropriante imitido na posse dos bens. Fala a lei em que o seja provisòriamente $e$, do ponto de vista jurídico, tal se dá. Uma vez decretada a expropriação, o poder público - na quase totalidade dos casos, já o dissemos - alega urgência e, então, é imitido na posse, a título provisório. E, durante o processo de expropriação permanece, do ponto de vista técnico-jurídico, a título provisório, na posse do bem. Finalmente, tal posse passará a ter caráter definitivo, vindo 0 expropriado também a perder a propriedade do bem.

No entanto, para o expropriado, o problema se apresenta da seguinte forma. Há um fato incontestável e fundamental ao justo equacionamento do problema: via de regra, imediatamente após ao decreto da expropriação, perde o expropriado a posse do bem, ou seja, não pode mais usar o bem. E o expropriado custo tempo enorme a receber a integralidade da indenização, que a Constituição diz The deve ser paga justa e prèviamente. Pela imensa frequência com que o problema assim se coloca, na prática, impõem-se que the seja, diante de tal situação, dada uma solução legal. Aliás, tal diagnóstico é de tal evidência, que os "Considerando" do decreto-lei 1.075, os tem por relevantes, tendo sido mesmo baixado o decreto-lei citado em virtude do permissão constitucional, que dá ao Executivo o direito de legislar, quando houver perigo para a segurança nacional, através de decretos leis. Desta forma, pois os problemas originados, principalmente pelas desapropriações no município de São Paulo, de suma gravidade, chamaram a atenção do govêrno para reformulação da lei. Todavia, especialmente com vistas ao problema da imissão liminar, a reforma da mesma, neste ponto, em nosso sentir é defeituosa, destinando-se este trabalho a apresentar conclusões conducentes à correção dos vícios existentes, quer no decreto-Lei 1.075, quer na Lei das Desapropriações em geral.

Assim, o problema a ser resolvido pela legislação ordinária, deve: $\left.1^{\circ}\right)$ partir da realidade social, e formular uma solução que permita ao proprietário, cujo bem foi objeto de expropriação, com imissão liminar de posse, da autoridade expropriante, desde logo, adquirir outro bem, e quanto possível, igual ao anterior; $2 .^{\circ}$ ) tal solução é tanto mais recomendável, pela circunstância de a Constituição referir-se expressamente a indenização justa e prévia. 


\section{3 - A imissão e a posição do expropriado.}

A indenização provisória, na forma do decreto-lei 3.365, de 1941 era e continua a ser principalmente para os casos não compreendidos no decreto-lei 1.075, de 22-1-1969 notàvelmente inferior ao valor efetivamente justo da indenização, a qual sòmente depois de transitada em julgado a decisão da segunda instância é determinada. A administração sempre e invariàvelmente escolhe o caminho de depósito, independentemente da instrução sumária, a que alude o artigo 15, do decreto-lei 3.365, na forma do artigo 685 do Código de Processo Civil. Assim, recebendo muito pouco, o expropriado perde $\circ$ bem, e a indenização, que venha lhe permitir realmente, adquirir outro bem, demorará muito tempo. O processo expropriatório, ninguém honestamente o ignora, é demorado. Ao lado da sobrecarga de serviço dos centros urbanos mais populosos, há sempre, por lei, o recurso ex-offício, existente em benefício do poder expropriante. Então, necessàriamente, t'endo em vista que o depósito inicial é sempre inferior ao valor afinal apurado, e sendo o ente expropriante, invariàvelmente, condenado, daí, nasce, sempre, e por via de consequência, o recurso ex-officio.

Ao lado desta demora, que lamentàvelmente é quase inerente à vida judiciária brasileira, por outra parte é também demorado o pagamento efetivo. Esta é a realidade atual, a qual não se compadece com os dizeres da Constituição. Destas considerações resulta límpida a seguinte realidade, a qual não pode o legislador ordinário ficar indiferente:

a) - o expropriado, na quase totalidade dos casos, perde desde logo a possibilidade de utilização econômica da propriedade, porque the é arrebatada a posse e, isto, mediante pagamento de quantia sabida e reconhecida irrisória; b) - a justa e prévia indenização, sòmente o expropriado a receberá, efetivamente, depois de mais ou menos uns dois anos ou até mais.

$\mathrm{Na}$ verdade, é imprescindível, encerar-se esta realidade. E é uma realidade acima de tudo econômica e humana. $O$ expropriado é desalojado do imóvel por êle ocupado e na verdade, não pode adquirir outro equivalente. Sòmente poderá adquirir outro bastante inferior. Mas, mesmo que nêle não resida, é proprietário do bem, garantindo-lhe a Constituição o direito de propriedade.

O ideal de uma regulamentação jurídica, e tal disciplina jurídica seria a mais afeiçoada à Constituição, seria aquela que, no momento do desapossamento, já desse ao expropriado o justo pagamento do 
preço. Certamente, tal disciplina compader-se-ia mais com os têrmos da indenização justa e prévia. No entanto, parece que é pràticamenie impossível obter-se uma tradução prática dessa posição ideal, por isso, ela permanece puramente ideal. $O$ que incumbe, é conseguir-se uma disciplina que, o mais possível, dela se aproxime, eliminando o quanto possível a situação em que permanece o expropriado antes de ser indenizado afinal.

Examinemos, porém os problemas suscitados pela expropriação, que se coloca como exceção ou limitação ao direito de propriedade e, como, disto emerge o conceito de indenização.

\section{4 - A expropriação e o direito de propriedade}

A doutrina tem apontado diversas teorias que pretendem explicar o fundamento jurídico da expropriação. Aponta-se, na origem do instituto, a expropriação como sendo ato do rei, ao qual se submetia o súdito, o que deu origem à chamada teoria do fisco. Houve sempre, històricamente, a tentativa do Poder Público em tentar subtrair o aío expropriatório ao contrôle - posterior - do Poder Público. Tratar-se-ia de um ato de império e, assim, por sua natureza, refratária a qualquer limitação. (V. sôbre isto, Fritz Fleiner e José Canasi, El Justiprecio, cit. n. ${ }^{\circ} 7$, pag. 19-20). Como resquício da teoria do fisco, pode-se dizer que 0 ato expropriatório, conquanto submetido, hodiernamente, ao contrôle jurisdicional, no Estado de Direito, conservou, todavia, o caráter de ato discricionário do Estado. E isto no sentido de que, a necessidade e inierêsse social, a conveniência ou inconveniência a respeito de se decretar ou não a expropriação, é própria e privativa, na medida em que tal conveniência, necessidade, interêsse social, seja desconforme a lei, permissiva da expropriação.

O probelma fundamentalmente mais importante, como já o dissemos, é o da avaliação e o pagamento respectivo. E êle é importante, não sòmente do ponío de vista prático, como também teórico. Pràticamente avulta a importância do mesmo pela circunstância de, na quase totalidade de expropriações, sòmente se discutir no processo expropriatório o problema atinente ao valor. (V., decreto-lei n. ${ }^{\circ} 3.365$, artigo n. ${ }^{\circ} 20$ ). Do ponto de vista teórico, avulta o problema de indenização, pelo seguinte: $1^{\circ}$ ) se, na verdade, o ato expropriatório é ato discricionário e, por tanto, não há que se discutir sôbre a necessidade, conveniência, eíc., resta sòmente a discussão de como, com base no direito, dizer-se o que é indenizável, e o que não o é, tendo por causa da expropriação; $2^{\circ}$ ) de outra parte, e ainda sob 
uma perspectiva teórica, há que se considerar que a construção do conceito de que seja indenização tem de ser feita observando-se as coordenadas do direito de propriedade. Assim, antes de se tratar de indenização pròpriamente dita, indispensável é rápida referência so próprio direito de propriedade, examinando-se-lhe, conquanto perfunctòriamente, o fundamento em função do qual é o mesmo admitido, nos ordenamentos jurídicos contemporâneos. Conjuntamente com o exame do direito de propriedade, procuraremos traçar as linhas principais, em função das quais se devem compreender os limites da indenização devida ao expropriado.

Aceita-se, nos dias de hoje, quase que pacificamente, que o direito de propriedade existe, é defendido e protegido, porque se reconhece no mesmo uma função social. Não se justificaria tal direito, se êle fôsse contrário à conveniência social. Assim, subordina-se o direito de propriedade, o seu exercício, as limitações a ele opostas, ao interêsse coletivo. Em contra partida, porém, tais limitações e restrições, tem de respeitar a integridade do direito de propriedade, pois caso contrário, as limiłações importariam em destruição do próprio direito.

Fundam os tratadistas, o direito de propriedade e a sua indenização, correlacionando-os com a hipótese de expropriação, nos seguintes pontos: $\left.1 .^{\circ}\right)$ no direito natural, pelo qual, existindo a propriedade, seria de direito natural que, ocorrendo a expropriação, se operasse verdadeira substituição de valores; $\mathbf{2}^{\circ}$ ) na clamada teoria constitucional, ao lado do qual derivaria o direito à indenização de imposição constitucional, ao lado do próprio direito de propriedade; $3^{\circ}{ }^{\circ}$ ) segundo um terceiro entendimento, deve haver indenização quando: a) a lei o preveja, ou, então b) quando o costume o ordene.

A teoria do direito natural fornece uma explicação meta-jurídica, e, por isso, escusamo-nos de discutíla. As teorias constitucional e as que fazem derivar a indenização da lei, conquanto sejam teorias que se assentam no direito positivo, não são satisfatórios. E não nos parece satisfatória, pela circunstância de, apenas dizer quando há indenização, e não consubstanciar, em seu bojo, o esclarecimento da razão porque se indenizar, com o que claramente se fixariam os limites da mesma.

Apontam os tratadistas, porém, uma outra teoria que nos parece a que, mais satisfatòriamente, fornece elementos para compreender-se a expropriação e as respectivas consequências, potencialmente danosas, cuja principal, para o expropriado, é a de se evitar que êle 
sofra alteração quantitativa no seu patrimônio. É a teoria que diz que, ao procedimento expropriatório e a indenização, tem de observar sempre a igualdade de todos perante a lei. Assim, por essa teoria, veda-se que uma carga desigual atinja alguns cidadãos, mais do que a outros. E consequentemente, segue-se que todo sacrifício especial, deve ser compensado monetàriamente. É ela, entre nós, direito positivo constitucional (Emenda Constitucional n. ${ }^{\circ}$ 1, Artigo 153, $\S 10^{\circ}$ ). (V. para um resumo destas teorias, Canasi, op. cit. n. ${ }^{\circ}$ 10, pág. 31 letras a a e).

Realmente, com a expropriação, opera-se uma transferência de propriedade, passando o bem do particular, a ser bem público. Desta forma, já no paírimônio do particular, uma modificação qualitativa, porquanto, onde existia um bem móvel ou imóvel, passará a haver dinheiro. No entanto, para que a mudança seja apenas qualitativa, e não quantitativa, é imprescindível que o expropriado receba justa indenização. Caso contrário, além de perder o bem, verificando-se mudança qualitativa, haveria também quantitativa, porquanto, ficaria o expropirado, mais pobre (Veja-se o n. ${ }^{\circ} 7$, adiante sôbre as aplicações práticas desse entendimento.

\section{5 - A lei ordinária não deve distinguir, quando a lei constifucio- nal a que ela, genèticamente se liga, não distingue.}

É ponto absolutamente pacífico em hermenêutica e aplicação das leis, que o aplicador da norma, ao interpretá-la, não deve fazer distinções, além das efetivamente existentes na lei. $O$ aplicador da regra jurídica transfunde, nos fatos da vida a ela submetidos, o mandamento contido na lei. Não poderá inovar, juntando a sua vontade àquela da lei, pois se o fizesse, deixaria de ser mero aplicador da lei e passaria a ser também legislador.

Todavia, há uma hipótese, em que o próprio legislador ordinário fica também na submissão de uma lei maior, que a Constitucional. O legislador ordinário deve legislar dentro da bitola de preceito de nível constitucional, para que, mercê da lei ordinária, se lhes possa conferir praticabilidade, mas não poderá nunca desrespeitar aquêle preceito. E, justamente para que possa guardar tal respeito, lícito não the será distinguir, onde não foi distinguido pelo legislador constitucional. Com efeito, se o legislador constitucional - exemplificativamente, outorga uma dada garantia, e o legislador ordinário, ao disciplinar a mesma, faz distinções, que impliquem em favorecer tais ou quais pessoas, e não tais e quais, certamente, a lei ordinária não se compadece com a constitucional. Se existe na Constitui- 
ção uma garantia, ampla e indistinta, não há como angustiá-la, através do expediente da legislação ordinária.

O texto constitucional, disciplinar o direito de expropriação, fala, indistinta e genèricamente, em indenização justa e prévia. Aliás, - legislador constitucional considera a expropriação como exceção ao direito de propriedade, o que deve - em caso de dúvida - conduzir o hermeneuta e aplicador da Lei a pender pela indenização sempre maior, a qual, no caso da expropriação, representa um substituto de propriedade imobiliária. Não há no texto distinção, restrição ou especificação alguma. Òbviamente, o legislador ordinário, ao disciplinar em que consiste indenização justa e prévia, não poderá especificar ou distinguir. As distinções que o legislador constitucional desejou fazer constam da própria Constituição (art. 161). Se o fizer, - legislador ordinário estará delimitando arbitràriamente um rexto constitucional. Os atributos da indistinção - defesa da propriedade de todos - e do caráter genérico da indenização justa e prévia, devem ser transportados para a lei ordinária, constituindo-se também em atributos desta, sem alterações.

Acrescente-se que não pode o legislador ordinário, em nosso sentir, sequer favorecer a determinadas pessoas, com um procedimento mais favorável, inaplicável a outras pessoas, conquanto - em última análise e afinal - todos venham a receber uma indenização havida como justa. Sequer processualmente não poderá haver distinções e favores, do legislador ordinário, se inexistentes, umas e outras, no texto constitucional. E isto porque, o que é favor para uns, òbviamente, será desfavor para outros.

Nesta censura, afigura-se-nos, incide o decreto 1.075, de 22 de janeiro de 1970 , em seu artigo $6 .^{\circ}$. Dispõe-se aí, que a forma preliminar de indenização (especialmente, através de peritagem, conforme artigo $2 .^{\circ}$, do mesmo decreto-lei), aplica-se exclusivamente, a "desapropriação de prédio residencial urbano, habitado pelo proprietário ou compromissário comprador...". Assim, quem não estiver nessa situação jurídica, ficará, ipso facto, submetido a um regime jurídico menos favorável.

Se a forma disciplinada no artigo $2 .^{\circ}$ do decreto-lei é mais favorável e ninguém di-lo-á o contrário - o decreto-lei discriminou, onde não deveria discriminar. A circunstância de se tratar de um decreto-lei, e, pois, constituir-se numa fonte de inovação de ordem jurídica, através do Poder Executivo, certamente, não confere ao Poder Executivo a possibilidade de contravir à Constituição Federal. 
O decreto-lei, nos limites da competência legislativa outorgada pela Constituição, ao Poder Executivo, conferiu a êste o direito de legislar, em determinadas circunstâncias emergenciais, sem que, no entanto, seja ao mesmo viável contravir a Lei Maior. Dir-se-á, no entanto, que a inspiração do citado decreto-lei foi a de "evitar grave risco à segurança nacional" (sic, "considerando") e, assim, seria inerente a tal tipo de inovação na ordem jurídica, certas discriminações, as quais só seriam inconstitucionais nas formas tradicionais de legislação. Não nos parece, no entanto, exata a argumentação. Na verdade, o decretolei em rigorosamente disciplinado na Constituição, nada havendo, absolutamente nada, que autorize, tal entendimento. Pelo contrário, é diversamente que se deve entender.

O decreto-lei é forma de legislar emergencial, ou se se quiser mesmo, atípica ou até mesmo anormal. Só por exceção é que assim se deve legislar. Se assim é, não se poderá aumentar aquilo que, pela sua própria natureza, já constitue uma exceção. O que o Poder Executivo pode por causa da permissão constitucional e ocorrentes os respectivos pressupostos, é legislar por decretos-leis. No entanto, tal como o legislador ordinário, só pode fazê-lo também constitucionalmente.

Por outro lado, não se pode confundir a motivação, extra ou meta jurídica de um decreto-lei, com o próprio decreto-lei, que se tem de conformar com todo um sistema jurídico, principalmente o constitucional Assim, se foi o decreto-lei emergido de uma situação anormal, a realidade é que êle criou permanentemente uma dualidade de sistemas jurídicos, de indenização prévia: a) os casos favorecidos do art. $6 .^{\circ}$; e b) os demais, aos quais não se aplicam os favores do citado art. $6 .^{\circ}$. Mesmo havendo motivação justificadora do decrefo-lei - e êle realmente existiu e continua existindo... não poderá o mesmo criar permanentemente dois sistemas jurídicos, um favorável, e outro não, distinguindo onde não é lícito, nem ao decreto-lei, e nem a lei, distinguir. Tal dualidade de sistemas jurídicos, tendo assumido existência permanente, talvez, não se compadeça, em verdade, com a Constituição federal (artigo 153, § 22).

Assim, se o sistema do artigo $2 .^{\circ}$ ajusta-se mais perfeitamente ao conceito de indenização p ré vi a, porque por êle o ex-propriado recebe, liminarmente, mais do que receberia pelo outro sistema, não se justifica a existência deste sistema mais desfavorável, quando o texto constitucional é indistinto.

Assim, afigura-se-nos, não seria absurdo sustentar que $\circ$ artigo 
6. é inconstitucional, onde distingue, pois distingue aberrantemente, contra o texto constitucional, que nada especifica, e que êle ao lado de outros preceitos - se propôs a regulamentar.

\section{6 - A inconveniểncia de dualidade de sistemas jurídicos para situações iguais. A forma de prover às necessidades do Poder Público, nas melhorias urbanas. $O$ interêsse público é superior ao individual, mas não se pode, por isso, sub- verter os próprios direitos do particular.}

Não são estranhos, de todo, à vida da legislação brasileira, do passado e de hoje, a existência simultânea de dois sistemas jurídicos, a regerem grupos de hipóteses pràticamente idênticas. Atualmente, por exemplo, temos o sistema inquilinato (Lei 4494, de 1964), a disciplinar as locações residenciais a ela submetidas; e, ao lado desta, também regendo locações residenciais, o decreto-lei $n .^{\circ} 4$, e Código Civil, pela circunstância de os aluguéis dos imóveis, cujo habite-se foi expedido depois da Lei de Estímulos à Construção Civil, terem tido os respectivos aluguéis liberados. Não se trata, porém, de desigualdade absoluta, porquanto a sisfiemática da Lei do Inquilinato prevê uma forma de melhoria do valor dos aluguéis. Não há, pois, contraste entre aluguéis congelados e não congelados, de forma total. Pretende-se, com o curso do tempo, chegar-se à uniformidade. $E$ a meta a ser conseguida por virtudes inerentes ao próprio sistema.

No entanto, para o caso citado, das locações, há razões de fato, que seriam quase que insuperáveis: $1^{\circ}$ ) durante mais de vinte anos, viu-se o país submetido às leis de "exceção" do inquilinato, que, de exceção, só tinham o nome; $2^{\circ}{ }^{\circ}$ ) certamente, a liberação brusca dos aluguéis, traria terrível dano ao país; $3 .^{\circ}$ ) ainda, o setor da construção civil é o que mais absorve mão de obra e, podendo o govêrno se utilizar - como o fêz, com a Lei de Estímulos à Construção Civil - de uma forma incentivadora de tal atividade, resolvida estaria, em parte, um dos problemas sociais magnos do Brasil: o da necessidade imperiosa de absorver mão de obra.

No caso, contudo, da expropriação, tudo é diferente. A primeira fundamental razão, que é, para o jurista a definitiva, é que existe preceito constitucional específico (art. 153, § 22), o qual inviabiliza qualquer diștinção, o que não se verifica em matéria de locação, por exemplo.

A forma do Poder Público prover às suas necessidades, quer, na última análise são o reflexo das necessidades coletivas de tôda a 
população, dever ser a tributação. A tributária tem, certamente, tôdas as vantagens, e nenhuma desvantagem. A tributária irá atingir aquêle que está em condições de pagar, salvo imperfeição do sistema positivo, que deverá ser corrigida. Assim, se o Poder Público necessita de mais dinheiro, para fazer reformar e alinhar-se aos anseios de progresso da população, deverá aumentar a tributação. Não há, outra saída. Os recursos oriundos da tributação podem ser conseguidos sem que alguns sejam mais injustamente sacrificados, em nome do interêsse coletivo.

O sacrifício do direito de propriedade, ou melhor, a substituição da propriedade de um bem, pelo seu equivalente, ocorre, em homenagem à realidade jurídico-constitucional que valoriza o interêsse público superior ao particular.

No entanto, o fato do interêsse público ser superior ao particular, não pode levar o legislador ordinário, e nem o aplicador da lei, a ferir direitios dos particulares. $O$ interêsse público, bem como o particular, fundamentalmente, encontram-se delimitados na Constituição Federal.

Desta forma, nada além dessa delimitação constitucional, será legítimo, com base no interêsse público, sôbre o do particular, para lesar direitos dêstes.

Assim, se a Constituição fala em direito à expropriação com indenização justa e prévia, aí estão definidos intransponivelmente o interêsse público e o particular. $O$ interêsse público fêz com que a propriedade individual ceda diante do direito de expropriação; 0 interêsse particular, porém, também considerado pelo legislador constifucional, diz que a propriedade sòmente sucumbirá em virtude de indenização justa e prévia, que substituirá o bem expropriado.

A medida, pois, da submissão do interêsse particular ao público, encontra-se na Constituição.

Assim, preponderância de interêsse é uma coisa; lesão de direitos, em nome da exacerbação ilegal de tal preponderância, é outra. A preponderância está definitiva na Constituição e tem que ser exercida nesses limites e correlatamente, respeitados os direitos dos particulares, tal como também se definiu. O Poder Público ao exacerbar sua ação, invocando tal idéia, está lesando direitos. O legislador ordinário que, também assentado em tal idéia, legisle sem atentar para a Constituição, outrossim, estará agindo ilegalmente (no caso, inconstitucionalmente). 
Assim, quer a inspiração do decreto-lei 3.365 , quer a do próprio 1075, partiu dessa confusão. No entanto, desde 1946, em que se prescreveu na Constituição indenização justa e prévia, incumbia solucionar o assunto, sintonizando melhor a legislação ordinária à constitucional.

Focalizemos o assunto tendo em vista a chamada indenização provisória, que na sistemática positiva do direito expropriatório é tratada erradamente. Em verdade, há uma dualidade de sistemas, tangentemente a essa indenização prévia. Nos casos do artigo $6 .^{\circ}$ do decreto-lei 1.075 o Poder Público é, liminarmente, obrigado a dispender mais e, nos outros casos, não é obrigado a dispender tanto.

Por outras palavras, a indenização liminar, na hipótese do artigo $6 .^{\circ}$ é justa ou mais justa, ao passo que as dos outros casos é, òbviamente, menos justa.

Vejamos porque dizemos mais justa, e menos justa. $O$ conceito de justiça, na espécie, só pode ser um: é dar-se pelo bem expropriado o "quantum" que o mesmo valha no mercado. Isto é que é indenização justa e prévia. Na medida em que isto não ocorra, a indenização é, necessàriamente, injusta. Não há como fugir dêste raciocínio.

Evidentemente, a fuga do Poder Público a essa evidência, tem a sua explicação. Ela consiste em que o Poder Público, não dispendendo desde logo, a importância do bem (isto é, aproximadamente o preço justo do mesmo), poderá fazer maiores reformas e mais desapropriações. Isto está claro.

No entanto, não é justo, nem jurídico, e afronta o sistema, que as reformas, para o benefício da coletividade, se façam com o sacrifício patrimonial localizado dos expropriados, alguns dos membros da coletividade. Êstes, então, estariam arcando com mais do que os outros. E isto pela circunstância de, além de pagarem normalmente os impostos que lhes incumbem por lei, sofrem desfalque no seu patrimônio, tendo em vista tais ou quais reformas, porque tiveram seus bens expropriados.

Todavia, pretendendo responder a tôdas essas considerações, - que se tem conseguido, até hoje, é sustentar se que o depósito colocado como requisito, para a imissão liminar de posse, não é indenização. $E$, não sendo indenização, na verdade e consequentemente, não há que falar em justiça da indenização, eis que, desta última ainda não se trała. De indenização, haverá que se falar, tãosòmente, depois da sentença final. A própria Lei das Desapropriações 
(Decreto-lei n. ${ }^{\circ} 3.365$, do ano de 1941), em seu artigo 29 reza que "Efetuado o pagamento ou a consignação, expedir-se-á em favor do expropriante, mandado de imissão de posse, valendo a sentença como título hábil para a transcrição no registro de imóveis". Isto quer dizer que, a transcrição sòmente pode ser efetuada após o pagamento, o que significa que, antes do mesmo, não se consuma a expropriação, na sistemática da Lei das Desapropriações. É esta também a sistemática do direito argentino (of. Liñares Quintana, op. cit. tomo cit., n. ${ }^{\circ}$ 2.546, pag. 159). Acontece, porém, que esta argumentação deve ser analisada à luz do preceito constitucional, que determina que a indenização seja prévia e justa.

É da tradição do nosso direito à indenização - (Const. de 1891, art. $72, \S 17$, conquanto não falasse em justiça da indenização, acentuava que devia ser prévia; a de 1934, art. 113, § 17, fálava que devia ser prévia e justa; a Carta de 1937, referia-se à indenização prévia, cujo "conteúdo e os seus limites serão os definidos nas leis que lhe regularem o exercício" - artigo 122, § 14, verbis).

Assim, falou-se sempre que a indenização devia ser prévia. Os problemas originados pela expropriação em tempos anteriores à Carta de 1937, eram certamente menores do que os hodiernos, especialmente pela pràticamente inexistente inflação, naqueles tempos, e maior celeridade da justiça.

Face à Carta de 1937, que se despiu de disciplinar o conteúdo de uma garantia individual, o que revela profunda contradição, somente compreensível diante de condições políticas particulares e criticáveis. No fundo, se disse que se garantia uma coisa sem conteúdo. Òbviamente, é vital para qualquer instituto jurídico, o respectivo conteúdo. Desta forma, o decreto-lei 3.365, baixado na vigência dessa Carta, era então insuscetível de quaisquer críticas, nos planos do direito positivo.

Com a Constituição de 1946, porém, falou-se em indenização justa e prévia, e, diversamente da anterior, foi definido o conteúdo da indenização: tinha de ser justo.

De um posto de vista estritamente dogmático, examinando-se a legislação ordinária existente, pode-se sustentar que a expropriação, consumando-se tão sòmente com a transcrição, a qual, por sua vez, é necessàriamente, antecedida do pagamento, ou da consignação equivalente, o preceito está rigorosamente cumprido.

Todavia, possivelmente isso não acontece, por diversas razões. 
O preceito constitucional está inserido num rol de direitos e garantias, o que revela, acentuadamente, que não podem sofrer diminuição, e nem serem disciplinados por uma lei ou sistema que, na prática, se revele ineficiente. Na verdade, a prática nos mostra que é ineficaz o sistema jurídico, para que o expropriado possa, em breve tempo, receber sua indenização. De ouirra parte, não se pode ignorar que - citado preceito constitucional, disciplina uma garantia de índole econômica. Se se trata de uma garantia econômica, é absolutamenie inafastável que o intérprete e aplicador da lei, tem de verificar como atua a lei ordinária, em tornar prática aquela garantia. Se se vive num país de inflação crônica, e se esta prejudica o credor de dinheiro, - legislador ordinário não pode ignorar tal realidade, pois se o fizesse, estaria, ipso facto, ignorando o mandamento constitucional, ou Ihe dando uma interpretação formal, que não é a adequada.

O problema crucial, nas épocas de inflação é o do valor intrínseco da obrigação e não o do seu valor formal, ou seja, o que é definido monetàriamente, sem qualquer possibilidade de correção, embora o decurso do tempo corroa o dinheiro, por causa de sua desvalorização.

À vista destas considerações, a percentagem de $50 \%$ é pequena. O justo é que recebesse o expropriado $70 \%$ do valor, pois, indiscutivelmente, viria isto mais ao encontro do que dispõe a Constituição.

De outra parte, ainda, há que se ter presente - tratando-se de uma garantia econômica - que, sendo impossível receber a indenização em breve tempo, mesmo que ela seja justa, a demora não ensejará, de forma alguma, ao expropriado, uma recomposição equivalente em seu patrimônio. $E$ isto porque, recebendo uma parte no início do processo, e a outra parte, só afinal, não poderá o expropriado fazer um negócio de molde a conseguir uma situação igual à anterior.

Mais isto, pois, recomenda que os $70 \%$ sejam pagos liminarmente, com o que, indiscutivelmente, estar-se-á dando maior realidade prática do preceito constitucional

Em verdade, se o problema é econômico, é com base principalmente nos reflexos econômicos, que se tem de estudar o momento e o quantus da indenização. Caso contrário, em se tratando de um problema essencialmente econômico, se se cogitar do mesmo, com base estritamente no formalismo jurídico, estar-se-á fadado a praticar muita injustiça. 


\section{7 - A indenização e a desvalorização monetária na doutrina e jurisprudência comparadas. $O$ problema do valor como a questão prática fundamental.}

A construção da jurisprudência brasileira é notável - ao contrário do que se tem verificado na legislação ordinária - nas diretrizes fixadas, procurando sempre, ao máximo, adaptar a aplicação da lei à idéia matriz da indenização: a sua justiça. Desta forma, pois, o exame das decisões dos nossos tribunais revelam que sempre foram êles ao enconíro do legislador constitucional, extendendo ao máximo o direito de indenização, tendo em vista que, com a desapropriação não viesse o expropriado sofrer um dano. Ou seja, a indenização havida como justa, pela sentença, segue-se que o quantum respectivo e na medida dessa diminuição, viesse a indenização deixar de ser justa.

O tratadista argentino, José Canasi, analisou integralmente a jurisprudência de seu país, e de outros, procurando extrair da mesma as coordenadas básicas, em que se compreendem a desapropriação e indenização. Fixou as seguintes linhas mestras: $\left.1 .^{\circ}\right) \circ$ valor do bem deve ser objetivamente aferido, ou seja, pelo valor do mercado e tendo em vista o momento econômico (isto é, o instante da desapropriação); $2 .^{\circ}$ ) compreendem-se, na indenização, todos os danos que observem, relativamente a ela, uma relação de causa e efeito (Cf. op. cit. n. ${ }^{\circ} 19$, pág. 61).

Um outro tratadista argentino, citado por Canasi, observou que o têrmo indenização é mais adequado do que o de prêço, porquanto o primeiro é mais amplo, e compreende não só o prêço, como todos os danos emergentes do ato expropriatório. Deve-se excluir do conceito de indenização, de acôrdo com a jurisprudência argentina e norte-americana, qualquer dano potencial, entendimento êste perfeitamente aplicável ao direito brasileiro (Cf. Canasi, op. cit., cap. III, n. ${ }^{\circ} 40$, pág. 149).

Quanto à flutuação da moeda o direito argentino orientou-se no sentido da irrelevância da mesma na indenização, ao que nos pareceu, de modo verdadeiramente sistemático (Cf. Canasi, op. cit., n. ${ }^{\circ}$ 43 , pág. 150). Tal entendimento, porém não condiz com as premissas da própria doutrina argentina, pois a mais importante delas afirma que o ideal, na idenização, é que o expropriado não fique mais pobre (Cf. Canasi op. cit., n. ${ }^{\circ} 48$, pág. 159).

No direito alemão, diversamente, sempre se considerou relevante a depreciação monetária, que devia ser compensada em favor 
do expropriado (Cf. Canasi, op. cit. n. ${ }^{\circ}$ 10, pág. 37 e seguintes, onde se referem as fontes alemãs).

O direito francês, modernamente, não ficou infenso ao problema da inflação, admitindo, em 1954, por construção jurisprudencial da Côrte de Cassação, a correção monetária (Cf. Cáio Tácito, Correção Monetária nas Desapropriações, in R. D. A., vol., 84 - pág. 177; ainda, no direito francês, a propósito: Marcel Waline, in Revue de Droit Public et de la Science Politique, ano 1955, fascículo 1., págs. 184-186). Por causa dessa jurisprudência, originou-se a ordonnance de 7 de agôsto de 1957, que, no seu artigo 38, n. ${ }^{\circ} 7$, preceitou que a avaliação devia ser feita tendo em vista "o dia da fixação definitiva da indenização". Sucessivamente, em 1958, pela ordonnance n. ${ }^{\circ} 58.997$, de 23.10.1958, a indenização deve ser fixada no dia da decisão e, ainda, com base no artigo 26, dessa mesma ordonnance, se da dała da decisão definitiva, passar mais de um ano, e o pagamento não fôr feito, caberá nova avaliação. A doutrina itialiana, também recentemente, vencendo resistência que se pode dizer conservadora, se vem orientando pela possibilidade de considerar relevante, em favor do expropriado, a influência da desvalorização.

As diretrizes doutrinárias do direito italiano não se nos afiguram satisfatórias, na construção dos limites da indenização. A construção italiana, sintèticamente, fala que é lícita a desapropriação "salvo indenizzo" (art. 42), com o que ficou ao legislador ordinário a tarefa de definir os limites da indenização, pois a indenização, a que se refere a Lei Maior vem desacompanhada de quaisquer atributos ou adjetivos. No entanto, a lei que ainda rege a desapropriação no direito italiano (Lei de 25-VI-1865), é clara em exigir uma indenização rigorosamente justa, no sentido de vedar qualquer diminuição quani'tativa do patrimônio do expropriado. $\mathrm{O}$ art. 39, da citada lei, diz que a indenização deve ser "egualle a quello per il quale il proprietario, liberalmente determinato a vendere lo (i. é, o bem expropriado) avrebbe venduto e, respettivamente, altri, libero de comprarlo, lo avrebbe comprato" (Cf. a respeito da vigência dessa lei, Michele Rossano, Conselheiro da Côrte de Cassação, in Nuovissimo Digesto Italiano, vol. VI, verbete "espropriazione per pubblica utilità", capítulo V, "I diritto all "indennita", n. ${ }^{\circ} 34$, pág. 947). Verifica-se, desse artigo de lei, que levado o seu sentido às últimas consequências, desejadas pelo legislador italiano - segundo entendemos - não há porque deixar-se de considerar revelante o problema da desvalorização monetária. Não é, porém, a posição predominante na doutrina e jurisprudência, salvo raras exceções. Entende-se, no direito italiano, 
que o valor da indenização deve ser "determinato con riferimento al valore venale del bene espropiato al giorno della pronuncia 947; e tb. Enciclopédia del diritto, mesmo verbete, da autoria de Cuido Landi, n. ${ }^{\circ} 55$, pág. 871). Rossano, apoiando as reservas da jurisprudência italiana, a respeito da correção monetária, chega, em nosso sentir, a utilizar-se de argumento absolutamente inaceitável, pois a inflação seria "effeto del fortuito".

A jurisprudência italiana, contudo, orientou-se quase que pacificamente, no sentido de que "I'effeto della svalutazione monetária è stato ritenuto influente allorquando, per colpa della expropriante, l'espropriato abbia subito danni ingiusti" (Cf. Guido Landi, na Enciclopédia del Diritto, cit., verbete indicado, n. ${ }^{\circ} 55$, pág. 868 ).

O direito espanhol, embora de forma algo tímida, já tem lei a respeito do problema da correção, admitindo a mesma, em determinados casos (Cf. Cáio Tácito, op. cit., págs. 178-179).

Alguns exemplos esclarecem bem a nossa afirmação, da amplitude da orientação dos nossos tribunais, ao fixarem os contornos do que seja indenização, no direito brasileiro. As despesas de levantamento do prêço tem de recair sôbre o expropriante, em virtude de exigência dêste (TASP-ap. civ. 123.664, 4. ${ }^{\text {a }}$ Câmara, julgado em 16.7.1969, rel. Campos Gouvêa, in RT, vol. 406-183, V. tb. Washington de Barros Monteiro, Direito das Coisas, 1958, São Paulo, pág. 171).

O próprio pedido de certidões, necessários à defesa do expropriado, na ação expropriatória, deve ser carreado à conta do expropriante e incluem-se, no cálculo tôdas as despesas, não só as custas do processo, na fase ordinária, como as da própria execução. De um modo geral, a regra é a de que, havendo qualquer desfalque na indenização, não estará o expropriado recebendo o prêço justo (Cf. Seabra Fagundes, Da Desapropriação no Direito Brasileiro, 1949, pág. 432 e Eurico Sodré, A Desapropriação, 3. ${ }^{\circ}$ Edição, pág. 156).

$\mathrm{Na}$ hipótese de, em virtude da expropriação, por relação de causa e efeito ser necessário o desmonte e transporte de maquinária pesada, estas despesas serão por conta do expropriante. (1)

De um modo geral, o critério fundamental para que a indenização possa ser considerada justa, é o de que, o quantum a ser recebido

(1) TASP - apelação civil n.0 115.681, 4.a Câmara, julgado em 4.12.1968, rel. Campos Gouveia, in RT, vol. 404-213). 
pelo expropriado permita-lhe adquirir um imóvel igual ou equivalente. $\left({ }^{2}\right)$

Os salários do assistente do expropriado, tendo havido condenação do expropriante, atendendo pedido feito pelo expropriado, incluir-se-ão, também, na indenização, pois, do contrário, deixaria ela, nessa medida, de ser justa. $\left(^{3}\right)$

\section{8 - Os tribunais brasileiros e o problema da desatualização de valor apurado no processo expropriatório. Crítica à argu- mentação que negava reavaliação.}

Um outro aspecto, sumamente importante, no exame da conduta dos nossos tribunais, anteriormente à Lei 4.686, de 21 de junho de 1965, relativamente ao problema de indenização justa, é aquêle decorrente da demora do pagamento. Êste é sempre demorado, o que é particularmente agravado, nas épocas de inflação. No Brasil, como se tem vivido num clima crônico de inflação, assume proporções seríssimas tal conduta dos poderes públicos. Já se tem entendido que o prêço não é atualizável, mesmo que se evidencie, no momento do recebimento efetivo da indenização, uma discrepância absoluta, entre o valor real do bem e aquilo que, a título de "indenização, uma discrepância absoluta, entre o valor real do bem e aquilo que, a título de "indenização justa", vai se pago. Não há para êsse julgado possibilidade de atualização, mas sim e sòmente de sequestro da quantia devida pelo Poder Público. $\left({ }^{4}\right)$

Há que, liminarmente, se colocar esta questão nos seus devidos têrmos. Certamente, existem os juros moratórios, precisamente destinados a se acrescentarem ao capital devido pelo expropriante ao expropriado, nos casos de demora do pagamento do mesmo. Nos casos que se possam reputar situados dentro de uma faixa de normalidade, não se cogitava da possibilidade de nova avaliação, destinada a substituir aquela que serviu de base à sentença.

(2) TJSP - apelação cível n.o 112.781, 2.a Câmara, julgado em 10.7.1962, rel. Azevedo Francheschini, in RT, vol. 346-163 - (há voto vencido, entendendo que não se dera cumprimento ao artigo $26^{\circ}$ da Lei de Desapropriações, com a redação dada pela Lei Federal n.o 2.786, de 1956). O acórdão, porém, despreza essa restrição, orientando-se no sentido da indispensabilidade de que a indenização permita a aquisição de imóvel comparável ao expropriado.

(3) TJSP - apelação civil n.o 112.161, 1.a Câmara, iulgado em 28.11.1961, rel. Evaristo dos Santos, in RT, 344-214. V. também recursos de revista, in RT, vols. 210-302, 229-352 e 238 - 307; ainda, RT, vol. 183-235, 199-387, 213-182, 226-253 e 231-194.

(4) TJGB - apelação 20.663 - 5.a Câmara Civil, julgado em 30.10.1962 - rel. Mauro Gouveia Coelho, in RF, vol. 211-150 - Tratava-se de ação de enriquecimento sem causa, cumulada com perdas e danos - em 1962 os interessados não tinham recebidos uma indenização devida desde 1949. 
No entanto, não são poucos os exemplos práticos, onde a demora dos poderes públicos têm sido, às vềzes, de tal forma grande, que apesar dos juros, o valor a ser efetivamente recebido se distanciava de tal forma da realidade, que se colocava o problema consistente em saber se tal valor cumpriria ou não a regra, constitucional, da indenização justa. É exatamente nessas hipóteses de profunda desatualização, do valor fixado na sentença, que os nossos tribunais predominamtemente, já vinham admitindo a correção do valor em si (nova avaliação). Certamente, referimo-nos a uma jurisprudência anterior à lei de correção monetária (lei 4.685, de 21.6.65) pois, depois desta, é ela que deve ser aplicada. A jurisprudência referida justifica-se na tentativa de demonstrar o comportamento das nossas Côrtes de Justiça, diante de situações atentatórias, ao cânone constitucional, determinador de que a expropriação se faça, sempre, mediante indenização justa. Certamente, terão sido êstes julgados, que retratam situações reais, que motivaram o legislador, na feitura da lei da correção monetária.

Entendendo que nessas hipóteses, mesmo havendo demora excessiva aliada à desvalorização monetária, não deve haver atualização, há diversos julgados. $\left({ }^{5}\right)$

Já se argumentou que diversos sistemas de indenização existem, como o anglo-americano, pelo qual se reconhece ao credor só o seu direito à soma devida; ○ alemão, o suiço e o húngaro, onde além dos juros moratórios, se houver dano maior provado, êle deve ser ressarxido e finalmente, o brasileiro, que é o italiano e o francês, onde a demora só é compensável, pelos juros moratórios. E sendo o brasileiro o que só aceita os juros, não há que falar em injustiça, que não possa ser corrigida pelos juros. (TJSP, RT, vol. 321-209). No entanto, a regra do artigo 1061, do Código Civil, não poderá prevalecer diante do texto constitucional, como sendo uma regra suficiente. Há que além da compensação nela existente, atender ao dano provado pela demora, se existente e provado. Exatamente no sentido da impotência dos juros, argumenta-se em acórdão do TJGB (RF, 223-156).

Argumenta-se que, uma vez proferida a sentença, determinando - quantum da indenização e, principalmente, uma vez que a mesma, venha a se revestir da autoridade de coisa julgada, é impossível modificar-se o que foi decidido. Em verdade, embora a coisa julgada

(5) TJSP - apelação civil n. ${ }^{\circ}$ 109.939, da 1.a Câmara, julgado em 22.8.1961, in Rev. Trib. 321-208, recurso de revista (julgada improcedente, confirmando-se a tese do texto) n. 0 103.768, in RT, 342-288 - embargos infringentes, n. 0 103.147, in RT, 325.147. 
tenha uma importância fundamental, no direito processual civil, e no direito em geral, pois, que nela se encerra um bem na vida, insuscetível de qualquer modificação, o assunto comporta algumas considerações, que, naquelas situações, deveriam fazer com que não prevalecesse mesmo o princípio da imutabilidade da sentença.

Duas ordens fundamentais de considerações devem ser feitas. Saliente-se, também, que essas considerações valem principalmente, para a época anterior à lei da correção monetária, pois esta, fundamentalmente, veio atender, senão eliminar o problema com que se defrontavam nossos tribunais. A primeira consideração a ser feita é a de que a indenização justa é mandamento de índole constitucional. Desta forma, quer parecer, desde que, aparentemente, num dado caso, se verificasse o descumprimento da justa indenização, desde que a sentença de forma alguma expressa o valor justo, seria formalismo jurídico vazio de sentido, homenagear-se a coisa julgada, quando se constata que o conteúdo da mesma naquele caso, contém uma inconstitucionalidade.

Seria manifesto formalismo, diante da patente desatualização do quantum determinado pela sentença, falar-se em coisa julgada, mesmo porque, parece-nos que, em tese, seria viável até mesmo a utilização, pelo expropriado, da ação rescisória, fundado em que a decisão proferida seria atentória ao entendimento correto do direito objetivo (lei) no caso, de nível constitucional.

Todavia, ao lado dêsse argumento, existe outro e é justamente êste o que justifica, plenamente, a correção do valor consubstanciado na sentença. É ponto pacífico entre os doutrinadores, que a coisa julgada contém a definição de um comportamento jurídico, ao qual se atribui a virtude de imutabilidade e incontestabilidade. No entanto, é preciso bem compreender os graus da imutabilidade e incontestabilidade e, principalmente, tendo em vista a situação de fato que é pressuposta pela sentença. O comportamento definido na sentença, e tornado imutável pela coisa julgada, pressupõe uma data situação de fato. Corresponde, necessàriamente, a uma situação de fato. Óbviamente, pode-se colocar e frequentemente se coloca a questão, consistente no seguinte: modificando-se a situação de fato, que serviu de base à definição contida na sentença, como fica a validade da coisa julgada?

O que a mais autorizada doutrina vem firmando, já há tempos, é que modificando-se a siłtuação de fato, sôbre a qual se assentara a coisa julgada, ipso facto, na medida dessa modificação, não podia a coisa julgada prevalecer. É assim que se diz que, em certa medida, 
tôda a sentença, mesmo revestida da autoridade de coisa julgada, contém necessàriamenie - pela própria natureza das coisas - a cláusula rebus sic stantibus. Perfeito nêsse sentïdo é acórdão do TJGB RF, vol. 223-156) que se refere a fato posterior e desaparecimento da intocabilidade da coisa julgada.

Servindo-nos dessa doutrina, deve-se considerar que, se no momento da sentença a indenização era justa - e que do ponto de vista jurídico é incontestável, pois a justiça será aquela que a sentença ou acórdão disser que é - nem por isso, porém, tal definição deverá ser imutável. Ou seja, se se evidenciar que, no momento da execução da sentença - instante de efetivo recebimento - a indenização deixou, absolutamente de ser justa, òbviamente, será afirmação vazia de sentido, invocar-se a coisa julgada, para fins de não mudar o conteúdo da sentença. Tal conteúdo deverá ser modificado, pois que ter-se-á verificado, a inexatidão do conteúdo da sentença. Poderia o mesmo ser considerado justo, a época da prelação da mesma sucessivamente, todavia, com o decurso do tempo e por causa dêste, aliando-se a isto a desvalorização monetária, deixa de ser justo o mesmo conteúdo. Por essa razão, não se poderá invocar a coisa julgada, para fazer prevalecer uma decisão, cuja situação de fato é profundamente diversa daquela, que serviu de base a sentença.

Não há de forma alguma, que se invocar contra esta argumentação, o art. 800, do Código de Processo Civil, que dispõe: "A injustiça da sentença e a má apreciação da prova ou errônea interpretação do contrato não autorizam o exercício da ação rescisória". Verifica-se, por êste dispositivo, que tais vícios, não permitindo o uso da rescisória, não justificariam o desconhecimento da autoridade e imutabilidade da coisa julgada. No entanto, tais hipóteses do art. 800 , citado, são estruturalmente diversas das situações por nós discutidas. Quem fala em injustiça da sentença - é esta a hipótese que nos interessa - considera que a sentença, em si mesma, e no momento em que foi proferida, era injusta. Isto, de per si, não permite em que foi proferida, era injusta. Isto, de per si, não permite em que foi proferida e, assim, a sentença injusta deverá sempre prevalecer. Nos casos de desapropriação, a situação é manifestamente diversa. Em primeiro lugar a sentença que é preferida é, em si justa e no momento em que ela é, prolatada tem-se que ela bem retratada uma situação de fato: atribui ao bem e valor do mesmo naquele momento. Entretanto, com o passar do tempo e não efetivação oportuna do pagamento, ou seja, por êste fato superveniente à sentença 
e não contemporâneo ou anterior a ela, a sentença que era justa, passará a ser injusta. Consequentemente, o artigo 800 do Código de Processo Civil, é ininvocável para elidir o raciocínio feito.

Por êsses argumentos e outros mais (V. nêsse sentido, acórdão do TJGB, in RF, vol. 223-156), é que a nossa jurisprudência admitiu a alteração do valor, conforme inúmeros julgados, anteriores a lei de correção monetária. Assim por exemplo, iá se admitiu ação de expropriado visando complementação de prêço, pela desatualização do mesmo "permissão do desapropriante em executar o julgado, porque a Constituição impõe requisito básico para tanto, a justa indenização em dinheiro". (TJGB - apelação 46.726, 7. “ Câmara Civil, julgado em 12.8.1966, in RF, vol. 223-155). O lapso de tempo entre a fixação do prêço e o depósito, foi de 12 anos; RF, 219-126, 7. ${ }^{\text {a }}$ Câmara, julgado em 11-6-1965, rel. do sr. Marcelo Santiago Costa. (o voto vencido orientava a solução para a aplicação da lei sôbre a correção monetária). $\left({ }^{6}\right)$

Também, os nossos Tribunais, numa hipótese em que não foi possível executar a sentença, por causa da interposição de recurso extraordinário, tendo, por isso, o processo ficado paralizado por mais de 15 anos, aplicou o nosso Tribunal de Justiça correção de valor, antes mesmo da lei. (TJSP - apelação 64.497, 5. a Câmara, julgado em 1.3.1968, in RT., 397-135).

Recentemente o mesmo Tribunal de Justiça, constatando a ocorrência de efetivos prejuízos, pela demora, admitiu fôssem os mesmos pleiteados, sòmente que, deveriam sê-lo separadamente. No entanto, confirma-se, de qualquer forma, a tese da inoponibilidade da coisa julgada. (TJSP - in Boletim de Jurisprudência da Biblioteca de Tribunal de Justiça de São Paulo, vol. 1-17). Ainda do mesmo Tribunal, fundando-se essencialmente no fenômeno inflacionário, há outras decisões. ( $\left.{ }^{7}\right)$

Lamentàvelmente, porém, o Supremo Tribunal Federal, dogmàticamente, em sua Súmula 345, orientou-se no sentido de que "pela demora no pagamento de prêço da desapropriação não cabe indenização complementar, além dos juros". Certamente errou o Supremo Tribunal Federal, em emoldurar tal regra numa de suas súmulas. $\mathrm{Na}$ verdade, deveria ter fixado pelo menos que, quando a demora fôsse

(6) No mesmo sentido: TJSP-recurso de revista 109-939, fundando-se na desvalorização da moeda, como justificadora da alteração do valor, in RT, 347-271; apelação civil, n. 0 112.968, in RT 338-146; embargos, n.0s 85.609, in RF, vol. 192-223 e RDA vol. 58.240 (fundando-se na impotência dos juros de mora, para compensar a desvalorização).

(7) TJSP-embargos n.0 85.609, rel. Evaristo dos Santos, in RT, 296-224 e in RDA, vol. 63-161; Vide também do mesmo Tribunal, RT, vols. 266-273, 287-299. 
excessiva, e se verificasse desvalorização que tivesse, consideràvelmente, reduzido a substância da indenização, que se fizesse a reavaliação. Certamente, esta outra regra seria de aplicação difícil porquanto não teria o atributo da certeza, que inspirou a Súmula 345. No entanto, seria uma diretriz afeiçoada a Constituição Federal, e que inocorria com o conteúdo da citada Súmula. O comportamento do Supremo Tribunal Federal, porém, na aplicação da Súmula 345, não foi pacífico (V. decisões citadas na R.D.A., vol. 84, págs. 181-182).

De qualquer forma, essa jurisprudência serve como fonte histórica, para que, caso os índices de correção monetária não traduzam a realidade, nada impedirá, mas ao contrário, recomendará, se faça nova avaliação. Os fundamentos usados nesses acórdãos subsistem válidos pela respectiva origem constitucional, na hipótese concreta de insuficientes os índices de correção monetária.

\section{9 - A Lei 4.686 de 21 de junho de 1965 (Lei da Correção Mo- netária)}

Essa situação certamente inspirou o legislador e foi baixada a Lei 4.686, de 21.6.1965 (Lei da Correção Monetária). Esta lei, procurando obviar os males decorrentes da demora dos poderes públicos, no atendimento aos pedidos de pagamentos dos débitos oriundos da expropriação, estabeleceu correção monetária. Examinemos, primeiramente, os pontos capitais de dúvidas suscitadas por essa lei, para depois, concluirmos no sentido de melhorar a lei, para que fique mais adequada ao texto constitucional, e que, na verdade, não ocorre com a redação atual, o quanto seria desejável.

\section{a - A constitucionalidade da Lei}

Um primeiro aspecto duvidoso, na aplicação da lei, foi a respeitante a sua própria constitucionalidade, pois, com ela - argumentou-se - ter-se-ia estabelecido um previlégio para o expropriado, e que não se compadeceria com o princípio da isonomia. Pois, se todos são iguais perante a lei (Constituição, art. 153, § 1. ${ }^{\circ}$ ), certamente descabido seria o previlégio do direito a correção, em favor do expropriado, eis que isto implicaria num tratamento diferencialmente prejudicial aos poderes públicos. Realmente, observando as nossas leis, devemos constatar, no cenário legislativo nacional, que créditos há beneficiados por correção monetária (acentue-se, particularmente os fiscais) e outros que não o são. No entanto, essa discriminação não nos parece possa ser considerada inconstitucional, especialmente no caso particular da expropriação, porque é a própria Constituição que, imperativamente, impõe que a indenização seja justa. $E$, como 
o conceito de justiça, nessa hipótese, não poderá ser senão o da mais rigorosa equivalência de valor bem ao que venha ao valor em dinheiro que venha a ser pago ao expropriado. Em havendo demora, a correção procurará evitar o desasjustamento verificável. Aliás, precisametne pela demora do Poder Público, acarretando danos ao expropriado pela desvalorização do dinheiro, é que o próprio govêrno, recentemente procurou verdadeiramente coibir essa desatualização. Assim, localizando a nossa argumentação em campo de valor intrínseco do débito do expropriado, parece insustentável seja a lei 4.686, de 21.6.1965, inconstitucional. Nesse sentido, manifestou-se seguida e reiteradamente o Supremo Tribunal Federal, podendo-se afirmar, que a lei é absolutamente constitucional. ${ }^{(8)}$

Diversamente, porém, havia entendido o Consultor Geral da República, Adroaldo Mesquita da Costa, (Proc. PR., 13.311-66, in RDA, vol. 84-248. O Parecer do Consultor Geral da República entendeu que a lei seria inconstitucional porque infringente ao: $\left.1 .^{\circ}\right)$ Ato Institucional n. ${ }^{\circ} 1$ (art. $5 .^{\circ}$ e $2^{\circ}$ ) ao art. $141, \S 3 .^{\circ}$ da Constituição Federal. Entendeu-se que a regra do art. $5 .^{\circ}$ do $\mathrm{Al} \mathrm{n} .^{\circ}$ I não distinguia entre aumento direto ou indireto de despesa e, assim "abrange qualquer lei que aumente a despesa pública"; de outra parte, e art. 141, § 3.॰ defende certos direitos ou situações, coníra a retroatividade das leis. (9)

(8) (S.T.F. - Rev. Trimestral de Jurisprudência: vols. 45-344 - recurso extraordinário 63.329, Tribunal Pleno, julgado em 18.4.68, rel. Min. Evandro Lins e Silva, sustentando que, se todos são iguais perante a lei e, se tomar por base e direito de propriedade, os que tiverem bens expropriados terão sua liberdade de negociar cerceada e, consequentemente, restringido. $O$ direito de propriedade, com $\circ$ que ficarão inferiorizadas em face de outros proprietários. O princípio da isonomia tem que se colocar numa perspectiva em que todos estejam em igualdade de condições, e que ocorreria se todos os proprietários forem comparados. O relator chegou mesmo até dispensar o prequestionamento da questão possibilitando, apesar da inocorrência, a manifestação do Supreho; diversamente de que já entendera (agravo 38.344 de 5.9.66) - que é requisito exigido em todos os recursos extraodrinários. Verifica-se, desta forma, pois o interêsse do Supremo em dar pela constitucionalidade da Lei 4.686, de 21.6.1965.

STF.RTJ - 45.795 - recurso extraordinário n. ${ }^{\circ} 63.268$ (Terceira Turma), julgado em 10.5.1968, rel. Min. Hermes Lima;

STF. RTJ - 46.205 - recurso extraordinário n. 0 63.318 (Tribunal Pleno), julgado em 18.4.1968, rel. Min. Nunes Leal;

STF-RTJ - 48.439 - recurso extraordinário n. ${ }^{\circ} 61.378$ (Terceira Turma), julgado em 29.11.1968, rel. Min. Thompson Flores;

STF-RTJ - 49.470 - recurso extraordinário n.० 63.218 (Tribunal Pleno), julgado em 18.4.1968, rel. Min. Vitor Nunes Leal, onde salienta que a Lei 4.686 nada mais fêz senão dar maior expressão prática a indenização que deve ser justa;

STF-RTJ - RT-396-390 - recurso extraordinário n.० 64.440 (Primeira Turma), julgado em 26.8.1968, rel. Min. Raphael de Barros Monteiro;

(9) Vejam-se, ainda, a respeito do assunto: sôbre correção monetária, RTJ, vol. 45-39 e RDA, vol. 92-219) (êste sôbre a interpretação do artigo 26, da lei n.० 4.686). 


\section{b - Interpretação da Lei 4.686 de 21 de junho de 1965.}

Em nosso sentir, a interpretação dada a Lei $n .^{\circ} 4.686$ deverá sempre, nos casos discutíveis, ser a mais favorável ao expropriado. Desta forma, havendo qualquer espécie de dúvida, esta não poderá ser interpretada em favor do Poder Público, pois a lei da correção monetária é um dos aspectos da tradução prática da defesa constitucional de direito de propriedade nos casos de expropriação.

A. Desta forma, pois, na indenização devida ao expropriado e respectiva atualização (correção monetária), dever-se-á levar em conta até a data do efetivo pagamento da indenização, pois, só nesse instante é que se opera de fato a indenização ao expropriado. Pode-se asseverar que, antes do recebimento efetivo da indenização, o expropriado tem apenas uma sentença exequível a seu favor; o seu patrimônio, no entanto, encontra-se até então desfalcado de bem expropriado. $\left({ }^{10}\right)$

Por essa razão, afiguram-se-nos criticáveis as decisões que entendem que a correção monetária é sòmente aplicável antes da decisão final. (11)

Pelas mesmas razões, outrossim, são passíveis de crítica, os entendimentos que admitem correção monetária exclusivamente na fase declaratória. $\left.{ }^{12}\right)$

Além das razões já referidas, há outras, que vão contra tais decisões (RDA, vol. 91-154, e RT, vol. 390-255), demonstrando que tal hermenêutica, além de negar à lei uma de suas funções fundamentais, desconhece o sentido da jurisprudência anterior a lei, que recomenda interpretação diversa. Examinemos êstes dois pontos.

Os problemas mais agudos e justamente quando mais se justifica a aplicação da correção monetária, surgem, precisamente, dep̃ois do trânsito em julgado da decisão. Efetivamente, se se reduzisse a correção monetária a fase ordinária do processo, seria ela aplicável desde que "decorrido prazo superior a um ano a partir da avaliação, e Juiz ou o Tribunal, antes da decisão final, determinará a correção monetária de valor apurado" (Lei 4.686, de 21.6.1965, art. 1. ${ }^{\circ}$, que acrescentou um parágrafo único, ao art. 26 da lei 3.365, de 1941).

Lògicamente, a proximidade do laudo a decisão, diminue o interêsse na aplicação da correção monetária. De outra parte, desde que

(10) TASP - in RT, vol. 395-252.

(11) STF - r. extraordinário n.0 61.295, in RDA, vol. 95-154.

(12) TASP - agravo de instrumento n.o 97.113, in RT, vol. 390-255. 
a sentença de primeira instância seja preferida logo após a perícia, mas a de segunda instância venha a demorar, isto fará com que se aplique a correção monetária em segunda instância, com o que de um modo geral estarão obviados os inconvenientes da demora do processo.

Desta forma, os problemas maiores surgirão quando, já de posse do ofício requisitório, o expropriado peça lhe seja efetuado o pagamento, e êste demore. Aqui, precisamente, aqui, é que sofrerá o seu grande prejuízo. Se se entendesse que a correção estava circunscrita a durabilidade do processo, na fase ordinária, estar-se-ia aplicando o remédio quando menos é necessário.

Releva lembrar que a jurisprudência anterior à lei, revelando a grande sensibilidade dos nossos tribunais, admitia nova avaliação (que econômica e jurìdicameníe fazia as vêzes de correção), justamente nos casos em que havia demora no pagamento do ofício requisitório, ou seja, depois, de terminada a fase ordinária do procedimento expropriatório.

Assim, pois, parece-nos que, uma vez efetuado o pagamento da quantia devida no ofício, dever-se-á, tendo em vista a demora apriorìsticamente impossível de ser conhecida - determinar a correção monetária respectiva, a ser feita entre a data da expedição do ofício e o momento do pagamento. Só assim estará o expropriado recebendo quantia, que possa jurìdicamente ser reputada equivalente ao valor do imóvel expropriado e, só desta forma, esta-se-á interpretada a lei 4.686 , de 1965, sob a inspiração do texto constitucional, ao qual se destinava dar vida prática.

Criticáveis tais como aquelas, as decisões que tendem inaplicável a lei na fase de execução. $\left({ }^{13}\right)$

Diversamente, porém, há decisões confirmatórias de que expõe no texto. $\left({ }^{14}\right)$

B - Por essa razão e na linha da mesma hermenêutica da Lei n. ${ }^{\circ} 4.686$, de 1965, é que deve ser aplicado a conta de liquidação e índice contemporâneo a ela, e não o do trânsito em julgado, pois é êste o mais favorável ao expropriado. $\left({ }^{15}\right)$

Verifica-se, por esta orientação, que a circunstância de haver

(13) TJSP - apelação n. ${ }^{\circ}$ 154.168, in RT, vol. 375-136.

(14) TASP - embargos infringentes, n.० 111.288, rel. Silvio de Amaral, in RT, vol. 401-238, salientando-se ser a lei aplicável, inclusive ex-officio.

(15) TASP - apelação n. ${ }^{\circ}$ 104.992, in RT, vol. 395-243; apelação 113.038, in RT, 400-243. 
trânsito em julgado (coisa julgada), não supera os problemas decorrentes da atualização do valor da sentença que, como se frisou são especial e particularmente mais agudos, justamente depois do trânsito em julgado.

STF - recurso extraordinário n. ${ }^{\circ} 63.218$ (Tribunal Pleno), in RTJ, vol. 49-470.

Assim criticável afigura-se-nos a posição que negue, na fase executória, a aplicação da lei. Deve-se, assim, entender que, "sentença final", no contexto da lei n. ${ }^{\circ} 4.686$, de 1965 e a vista do sentido ao alcance do texto constitucional, que servirá de escudo ao hermeneuta, aquela decisão ou sentença que encerre, efetivamente o procedimento expropriatório, e não aquela que tenha dirimido a controvérsia, na fase de conhecimento ou ordinário, da ação expropriatória $\left({ }^{16}\right)$

\section{C - A aplicabilidade da lei ex-officio}

Por isto justifica-se plenamente, que se aplique a lei da correção monetária mesmo ex-officio, na decisão de segunda instância, pois, caso isto não seja feito, poderá o interessado, ulteriormente solicitar tal providência, o que exigiria nova atividade jurisdicional. De mais a mais, além da providência se compadecer com o espírito e ratio essendi da lei, é perfeitramente aceitável diante da clareza e pereptoriedade do texto, o qual, desta forma, para ser aplicado - não fica condicionado a qualquer solicitação de expropriado. $\left({ }^{17}\right)$

Como argumento, de certa forma analógica, lembre-se a jurisprudência, pacífica e constante, de todos os nossos tribunais, consubstanciada na Súmula 254, do Supremo Tribunal, que diz: "Incluem-se os juros moratórios na liquidação, embora omisso o pedido inicial ou a condenação".

(16) TASP - apelação 97.730, rel. Ricardo Costa, in RT, vol. 399-470.

(17) STF - recurso extraordinário n. ${ }^{\circ}$ 63.218, rel. Victor Nunes Leal, in RTJ, vol. 49-470; v. também, RTJ, vol. 48-725.

TJSP - embargos infringentes, 153-146, in RT, vol. 383-105.

TASP - embargos infringentes 111.288, in RT, vol. 401-238; embargos infringentes 95.988, in RT, vol. 390-240 (fixando a orientação clara de que, omisso o julgado, a qualquer tempo é viável a aplicação da correção monetária.

TFR - apelação 21.175, in RF, vol. 220-120, confirmada em grau de embargos, in RF, vol. 224-98.

TJSP - agravo de instrumento, 161.611, in Revista de Jurisprudência, vol. 3-191, agravo de instrumento n. 0 156.556, in RT. 380-137.

Diversamente:

TJSP - apelação 155.77, in RT, 393-156, apelação 154.851, in RT 380-111. 


\section{D - A aplicação da lei aos processos iniciados anteriormente a ela.}

Outro problema, ainda pertinente a lei 4.686 , com que se defrontaram os Tribunais, foi precisamente o de saber se desde logo, vindo a vigorar tal lei, aplicar-se-ia ela ou não nos processos anteriormente iniciados. De um modo geral, os Tribunais entenderam que a lei se aplicava aos processos pendentes. Afigura-se-nos ainda nesse passo, correta a orientação dos Tribunais, pela circunstância da mesma ir ao encontro do texto constitucional, e evitar os problemas decorrentes verdadeiros litígios ulteriores - nos casos em que o pagamento não fôsse feito com alguma brevidade, solicitar o expropriado nova avaliação. De outra parte, a lei 4.686 , retirou o caráter indiscutivelmente justo porém inevitàvelmente arbitrário dos nossos tribunais, no sentido de não haver um limite exato, para se saber quanto caberia, e quando não, uma nova avaliação.

Assim a lei 4.686, reduziu o problema a dados objetivos, fixando inclusive os limites temporais de quando se pode contar a correção monetária. $\left.{ }^{18}\right)$.

\section{E - CRítICA A LEI 4.686, DE 1965}

Parece-nos que a lei 4.686 , todavia, merece uma crítica, quando delimita, temporalmente, as hipóteses em que há correção monetária para mais de um ano entre a avaliação e sentença, cabendo correção só para essas hipóteses. Quer parecer que, se o mandamento constitucional fala em indenização justa, não há razão para restringir os casos de atualização dos valôres, a hipótese do art. $1 .^{\circ}$ da leì 4.686. Seria mais justo e, pois, mais conforme ao pensamento do legislador constitucional, que, a indenização coubesse em todos os casos, mesmo, que passasse sòmente um mês. Haveria neste caso uma aplicação plena e integral de mandamento constitucional, o qual não comporta qualquer restrição, em lei ordinária. Certamente, ninguém a negará, que o estabelecimento do limite temporal da lei 4.686, para fins de excluir hipóteses de aplicação da correção monetária, importa numa restrição ao sentido e função do texto constitucional. $O$ rigorosamente jurídico, e assim, conforme a Constituição, seria a ausência absoluta de qualquer restrição, para que viesse a ser aplicada a correção monetária. Esta a nossa crítica a citada lei. A posição que entendo não deva ser feita qualquer restrição temporal, tangente-

(18) STF - recurso extraordinário 61.946 (RDA, vol. 95-102); 63-348 (RDA, vol. 95-97); 61.946 (RTJ, vol. 46-38); 63.329 (RTJ, vol. 45.344); 63.343 RTJ, vol. 49-317); 63-218 (RTJ, vol. 49-470); 63.316 (RTJ, vol .50-53); e agravo de instrumento n. 043.048 (RTJ, vol. 49-137). 
mente a correção monetária, não é nova. Segundo notícia o Prof. Caio Tácito, no seu já citado estudo na "Conferência de Desembargadores, reunida no Rio de Janeiro, aprovou-se tese do Desembargador Luiz Antonio de Andrade no sentido da inconstitucionalidade da lei, quando menciona a correção monetária ao decurso do prazo mínimo de um ano da data da avaliação. Entendeu-se que a correção monetária, defluindo diretamente do art. 141, § 16, da Constituição, deveria se fazer a qualquer tempo, não podendo a lei ordinária estabecer a contrário sensu, qualquer limite no tempo a sua eficácia" (V.R. D.A., vol. 84, pág. 183, n. ${ }^{\circ}$ ).

Não desejamos colocar o problema pròpriamente sob o prisma da inconstitucionalidade - muito embora, talvez, o pudéssemos fundamentadamente fazê-lo - mas sim, da indiscutível conveniência e justiça de se retirar da lei da correção monetária qualquer limitação de tempo, aplicando-se sempre a correção, desde que, òbviamente, houvesse o pressuposto da desvalorização monetária.

\section{II) - CONCLUSÕES E SUGESTÕES A RESPEITO DAS CONSIDE- RAÇÕES EXPEDIDAS.}

$\left.1 .^{\circ}\right)$ Parece-nos que, para haver um cumprimento real e autênti$\mathrm{co}$, da regra constitucional que fala em indenização justa e prévia, ao expropriado, dever-se-ia assegurar, desde a imissão liminar, em favor do Poder expropriado, um quantum verdadeiramente aproximado da indenização, ou seja, $70 \%$ do valor do imóvel, estimado através de peritagem, por perito nomeado pelo Juiz:

$\left.2 .^{\circ}\right)$ De outra parte, dever-se-ia aplicar a garantia referida acima a todos os proprietários, e não restringí-la sòmente àqueles que sejam domiciliados ou residam nos imóveis expropriados, eis que a Constituição garante a propriedade em si mesma e o faz de forma ampla e geral. O recebimento da quantia maior pelo expropriado, liminarmente, conquanto não seja possivelmente a integral, pois êsse "quantum" será completado afinal, afeiçoa-se mais no sentido da regra constitucional, que fala em ser a indenização justa e prévia. O sentido de prévia, colocado no capítulo de garantia individual, só pode ser o de garantir o indivíduo contra o Poder Público, e, certamente não é garantia íntegra a que, atualmente, o sistema legislativo ordinário proporciona àqueles que são expropriados. Por garantia tem de se entender algo que possa, eficientemente, contrapor-se ao Poder expropriante. Òbviamente, é da própria essência da idéia e da função técnico jurídica de garantia, que ela não possa ser atrofiada ou diminuída. Se o Poder expropriante pode procrastimar o pagamento 
da indenização, para certa classe de proprietários, porque a lei (decreto-lei 1.075) o permite esta classe estará sofrendo uma proteção menor, e que não se justifica.

3..$^{\circ}$ Quanto à correção monetária, ela deve ser integral, desde que presente e respectivo pressuposto fundamental, que é a desvalorização monetária. Não se justifica, ainda a luz do texto constitucional, que fala em indenização justa, que a justiça da indenização, naquilo que for correlacionada com a perda do valor do dinheiro, seja delimitada no tempo, havendo correção para certo período e não havendo para outro, embora presente, em ambos os períodos, a mesma desvalorização. A idéia de justiça, no caso específico da desvalorização, está direta e indissolùvelmente ligada à circunstância de que a desvalorização torna menos justa a indenização. Haja, pois, em que parcela houver essa desvalorização, menos exatamente deverá haver correção. Não desejamos colocar estas questões sob o prisma de sua constitucionalidade, ou não. Sustentamos que, possivelmente, poderiam ser apreciadas sob esse prisma. No entanto, se de uma parte não enfocamos o tema diretamente sob tal prisma, parece fora de tôda e qualquer dúvida que as soluções aqui propugnadas afeiçoam-se muito mais ao sentido e finalidade do texto constitucional, ao qual deve, fiel e inafatàvelmenie corresponder o direito ordinário, infra-constitucional. 